\section{BA Institute of \\ YK Business Administration \\ 六下 \\ Karachi \\ Leadership and Ideas for Tomorrow}

\section{Business Review}

Volume 9 Issue 1 January-June 2014

$1-1-2014$

\title{
Learning new management viewpoints: Recontextualizing strategic leadership in global and regional context
}

\author{
Ahmad Raza \\ School of Business and Economics, University of Management and Technology, Lahore, Pakistan \\ Hasan Sohaib Murad \\ School of Business and Economics, University of Management and Technology, Lahore, Pakistan
}

Follow this and additional works at: https://ir.iba.edu.pk/businessreview

Part of the Business Administration, Management, and Operations Commons, and the Leadership Studies Commons

\section{(c) (;)}

This work is licensed under a Creative Commons Attribution 4.0 International License.

\section{Recommended Citation}

Raza, A., \& Murad, H. S. (2014). Learning new management viewpoints: Recontextualizing strategic leadership in global and regional context. Business Review, 9(1), 103-109. Retrieved from https://doi.org/ $10.54784 / 1990-6587.1231$

This article is brought to you by iRepository for open access under the Creative Commons Attribution 4.0 License and is available at https://ir.iba.edu.pk/businessreview/vol9/iss1/8. For more information, please contact irepository@iba.edu.pk. 


\title{
DISCUSSION
}

\section{Learning New Management Viewpoints: Recontextualizing Strategic Leadership in Global and Regional Context}

\author{
Ahmad Raza, \\ Hasan Sohaib Murad \\ School of Business and Economics \\ University Of Management and Technology, Lahore Pakistan
}

\begin{abstract}
:
This paper makes a theoretical critique of the current paradigm on strategic leadership and proposes an epistemology of managerial practice as unfolded in the business contexts. It is argued that there exist diachotomic views of managerial practice based on profit-logic versus responsibilitylogic throughout the corporate world. The strategic leaders, instead of practicing one of these logics, should try to synthesize best of the both at the cognitive level and then apply them into the business and management environment. The rapid technological changes coupled with the profound cultural heterogeneity at the workplace have also created the determinants of humanly responsive and socially aware strategic leadership, which must respond sensibly to the hyper-transformative forces both at the regional as well as global level. Therefore, this paper suggest that strategic leaders in business, society and industry must cultivate a culture of courage, vision and will to transcend the established strategic straitjackets and usher into the new brave world of strategic opportunities and alliances.
\end{abstract}

Key words: Strategic Leadership, Epistemology, Managerial Practice, Profit Logic, Responsibility Logic.

\section{Context of Strategic Leadership}

The hyper transformative business markets of the world have created conditions, which impress upon the local as well as international business leaders, to think and lead their firms strategically. As described by Hitt etal (2003), "strategic leadership is the ability to anticipate, envision, maintain flexibility, and empower others to create strategic change as necessary". The emerging competitive scenarios of international finance, trade, communications technologies, and business have set the stage for a new kind of strategic leadership in the arena. Because of the unfolding complexity and fluidity of the business firm's global environments, strategic leaders must demonstrate an ability to interact across divergent behavioral and cultural recipes, and of course, in an unpredictable environment. They must demonstrate skills, personal and visionary in nature, which can influence the behaviors, thoughts and feelings of those with whom they work (Peters 2001).

Managing the human capital may be the most critical skill of strategic leadership (Collins,2001;Finkelstien etal, 1996).In the new millennium, intellectual capital, including a dynamic knowledge resourcefulness and an ability to create and commercialize innovation, can affect a strategic leader's success very significantly (Teece, 2000). Business contexts are also important in the effectiveness of strategic leaders performance. The competent strategic leaders also establish the context through which stakeholders can perform at peak efficiency 
(Kets de Vries, 1995).The firm without leadership may be a rudderless ship, wavering amongst the changing market winds and stormy business environment. The effects are experienced both within the firm and outside. The employees within the firm may suffer crisis of confidence, resulting in lower productivity, coupled with the stake holder's fears about the security of their investments. The primary focus of the strategic leadership happens to be its ability to manage the firm's operations effectively and sustain high performance overtime (Maccoby, 2001).

The locus of strategic leadership happens to be multidimensional in its nature. The strategic leaders are primarily concerned with managing large enterprises through others. They are not interested in managing the small business units (Hitt etal, 2003) They focus on rapid business and economic changes which may affect their business enterprise and its competitiveness as well as performance in the dynamic global environments. The failure of the strategic leaders, to respond quickly to the changing global business realities can weigh heavily upon the firms' strategic competitiveness and earn above average returns (Hitt etal, 2003).The global business competition is not just a competition between company versus company, or product versus product. It is also as Hamel and Prahald (1993) have commented a case of competing, "mindset versus mindset, managerial frame versus managerial frame". The strategic leaders must know how mindset of the firm be aligned with the mindset of the diverse global competitors, in order to retain the competitiveness and business advantage of the firm. The ability of strategic leader to interact across the cognitively complex competitive situations, demand from him the application of five interrelated competencies of, " foresight, systems thinking, visioning, motivating, and partnering”(Hammer and Stanton,1997).

Several strategic actions can be identified which characterize the structure of strategic leadership. As they have to execute the strategic intent of the firm in order to realize its strategic vision, understandings borne out of the analysis of internal and external environment of the firm constitute a prerequisite for the success of strategic leaders. Apart from this they should be capable enough of taking what Hitt etal (2003) have identified key strategic actions, which include interalia, "determining strategic direction, establishing balanced organizational controls, exploiting and maintaining core competencies, developing human capital, sustaining an effective organizational culture and emphasizing ethical practices". These strategic actions necessitate a higher order managerial skill from the strategic leaders. The effectiveness of the strategic leadership largely depend upon the fact that how far they can see into the futuristic market developments, how far they can make courageous yet calculable decisions in the midst of volatile global markets, and how far they can steer and maintain the sustainability of their firm in the unfolding strategic business realities (Lasserre, 2003; Hitt etal, 2003). Moreover, strategic leaders dealing with hyper transformative contexts in business, economy and technology, must demonstrate managerial skills to interact across different cultures and be able to respond to the diverse emotional and cultural needs of the stakeholders (Dreskey,2003;Schein,1985). Strategic leaders in many ways can change the organizational culture of the firm and transform it into social capital through which the competitive advantage of the firm in the marketplace can be retained. In the process strategic leaders have to formulate effective business strategies through a consultative partnership of the employees, peers, and superiors and desire to seek, what Hitt etal (2003) describe as a , "corrective feedback" about their, "difficult decisions and vision". This helps the strategic leaders to foster alliances and partnerships, both internally and externally for their firms, in order to materialize the broader features of their strategic vision (Hammer and Stanton, 1997). 
The top management of the firm holds the basic responsibility of strategic leadership, particularly the CEO (Hitt etal, 2003).Other significant position holders of strategic leadership within the firm may include members of board of directors, top management team and divisional general managers (Wright etal, 1996; Hitt etal.2003 ).Apart from their routine organizational responsibilities, strategic leaders have considerable decisionmaking powers which cannot be delegated (Finkelstein and Hambrick, 1996).As Hitt etal (2003) have commented very aptly that, " strategic leadership is an extremely complex, but critical, form of leadership. Strategies cannot be formulated and implemented to achieve above-average returns without effective strategic leaders". In the hyper transformative global economic scenario, effective strategic leadership needs to cultivate a mastery of technological innovation coupled with cultural imagination, to decide strategically and reach across the cultures to secure the financial and business advantage of their firms in a responsible manner (Deresky, 2003).

\section{Recontextualizing Global and Regional Managerial Practice}

The managerial practice of strategic leadership appears to be divided in two types of logic. There is one school and perhaps a dominant one in the management sciences, which takes managerial practice as rational, based on the analysis of 'forces' effecting strategic decisions, consequently leading to the competitive advantage of the firm. The strategic leader can lead his organization to sustained profitability and growth by rationally calculable and tangible business results (Friedman, 1962; Porter, 1979; Filbeck, 1996; Larson, 2004). The managerial practice remains justified unless it can lead to tangible growth and above average profits for the firm whatever the social, environmental or human consequences may be. The hallmark of strategic leadership is shown by its ability to apply strategy as a competitive advantage and value creating instrument which should lead the firm to tangible profits and financial gains in the marketplace (Hitt etal, 2003; Wright.1996). The logic of business enterprise is driven by a rational instrument, objectively, regardless of emotional, cultural and moral consequences of the profit making. The logic of profit maximization as a sole motive of business and economic enterprises is in itself a sufficient moral justification of 'competitive' operations in the market place. The notion of profit as a competitive advantage, culminating in a strategic decision, internalized by rational human actors is raised to the level of universal economic ethic. All strategic actions which terminate in measurable business profits have full 'moral' justification. One can see the simple law of profit logic operating underneath the myriad labyrinth of free (we may add blind and objective) rational market forces. Either your enterprise make sustainable competitive profits or you perish and languish in the marketplace. This crave for profit and competition as strategically plausible end has created an ugly mess of corporate exploitation of human as well as material resources having no regard for the human and moral costs of such actions. Several cases of corporate crime have been reported in the management literature, such as Enron Scandal, Union Carbide gas leakage at Bhopal in which thousands died and still thousands suffering, sexual and human abuses of particularly woman workforce by Nike contractors in Vietnam, sacrilegious shoes marketed in Bangladesh by Footwear International and Child labor malpractices in hand stitched footballs in Pakistan, stare at the face of ardent advocates of business as profit logic (Dreskey.2003; Hitt etal, 2003;Lassere, 2003).

The alternative to this view of business as profit logic is offered by responsibility logic. The proponents of responsibility logic argue that economic and business enterprise holds profound social responsibility towards the society and its moral concerns. The business 
enterprise must satisfy the emotional, moral and social needs of the society. The strategic leadership must formulate business strategies keeping in view the social contexts in which they operate. Several researchers have shown that a business firm can still yield profit, when it takes into consideration the environmental, social and moral contexts of the business into account (Mintzberg, 1994; Curcio etal 1996; Hall etal1998; Baldridge etal, 2004; Liljenquist etal, 2004). The relevance of responsibility logic as interpreted in moral and ethical terms has now assumed an indispensable significance in the managerial strategic leadership. The rapid global interdependence of business and technology has caused the managers to interact with diverse ethical and cultural values. As underscored by Dreskey (2003), "managers today are usually quite sensitive to issues of social responsibility and ethical behavior because of pressures from the public, from interest groups, from legal and governmental concerns, and from media coverage". We find several instances, in corporate world, where, profitability of the enterprise have been strategically realigned with ethical and human consequences of global strategic business engagements. For example, Reebok, a global athletics sports and fitness company have made clear commitment to human rights in carrying out its business across the globe with its contractors, subcontractors, suppliers and other business partners. They have what they call a, Reebok Human Rights Production Standards. Some of its important elements include, a healthy and safe work environment, refusal to do business with firms who indulge in child labor(under 14), refusal to work with firms that use forced labor motivated by political coercion or holding different political views, and a preference to do business with those firms who observe a 48 work week (Dreskey,2003).

The activities of firm cannot be seen in isolation from the larger social, ecological, moral and cultural implications (Allenby and Graedel, 1995). From manufacturing of a product to its marketing and eventual disposable have serious and tangible human social consequences. The MNCs' must develop a systemic view of their business and economic pursuit in the regional and local host countries. They must take note of the moral and cultural diversities across the globe and how these are going to be affected by them. The economic profitability must be balanced against the ecological and social consequences of such actions. As commented by Dreskey (2003) that, "MNCs must take the lead in dealing with ecological interdependence by integrating environmental factors into strategic planning. Along with an investment appraisal, a project feasibility study, and operational plans, such planning should include an environmental impact assessment”. The strategic leaders must fully know that the secret of sustainable business growth lies in realizing the strategic interdependence of business, economy, society and ecology. The real challenge for managerial strategic leadership in executing their strategic business goals across a culturally and morally diverse and unpredictable global business environment, reside in cultivating a uniform and worldwide posture on social and ethical responsibilities and see as to how it is implemented. (Dreskey, 2003)

Apart from the ecological dimensions of strategic business venture; the issues of corporate corruption, kickbacks, and business malpractices have raised serious concerns about the role of strategic leadership in handling the corrupt practices in their corporations. According to Mr. Peter Eigen, Chairman of German based non-governmental organization, Transparency International which keeps an eye on the corruption culture in the world, "The scale of bribe-paying by international corporations in the developing countries of the world is massive” (cit in Dreskey, 2003). Although US and other countries have enacted laws (e.g. Foreign Corrupt Practices Act of 1977) to check the corrupt practices in business and economy, nonetheless, it remains a menace which continuously engages the attention of 
global leaders. International corporations indulge in unethical practices in order to retain their competitive advantage over the rival companies in the local and regional markets. Even a company like IBM have not escaped the trap of corrupt practices in securing business with the largest commercial bank in Argentine, Banco de la Nacion (Dreskey, 2003). The international managers in order to make correct decisions in strategic business deals, with sound ethical considerations, must ponder whether a business decision or transaction is of questionable nature and therefore illegal and secondly, how the transaction could be made without indulging into scandalous business profits. They must integrate local moral structures on bribery and corruption with the international ethical code on business practices. The moral implication of the firm's business deals must be considered at the strategy formulation stage (Dreskey, 2003)The unabated desire to accumulate wealth as a social symbol of power and success have plagued a charade of politicians, bureaucrats, brokers, investors, soldiers and corporate leaders to connive and plunder the monetary, natural and human capital of societies across the world.

In the complex global business scenario, strategic leadership assumes a very significant, yet critical role. It is significant, because they formulate strategic business vision and critical, because they have to make courageous and difficult decisions to materialize it in the real world. Change and volatility is inherent in the strategic conditions. But, we must hasten to add that competitive business advantage at the cost of ethical, environmental and social abuses of human being is not justifiable under any kind of contingency or emergency. Business heuristics must corroborate into strategic paradigm the human consequences of strategic managerial decisions, synthesizing profit with ethical responsibility and accountability. We find a host of MNCs'emanating from North America and Europe, which include, Reebok, Liz Claiborne, Wal-mart, Avon, Sainsbury Plc, Otto Versand, who has implemented anti-sweatsshop Code of Conduct and Social Accountability 8000 to oversee that their business partners across the world strictly observe the ethical and moral aspect while fulfilling their business commitments. They take a strong note of child labor, human rights abuses, and forced labor at the work place and monitor closely the enforcement of ethical standards in the conduct of business by their global partners (Dreskey, 2003).Other developing economies of the South Asian region and Far Eastern region need to follow the suit and improve human conditions of business environment in a more elaborate way, because these regions are facing massive human rights and labor standards violations along with a high standing on the corruption index of Transparency International (cit. in, Dreskey, 2003).

The end of Cold War and ensuing 'technoglobalism' have unleashed complex cultural forces, which have created new strategic economic realities which demand from the local and global strategic leaders to shape their business and economic priorities in a flexible and creative fashion taking into full consideration the human consequences of their business agendas (Dreskey,2003,Lassere,2003). The one notable trend which has emerged very strongly is that of forming regional and bilateral strategic alliances in business and economy. NAFTA and ASEAN are two significant examples of strategic economic alliances. EU has also rapidly emerged as a strong strategic economic and business alliance. In the South Asian context, SAFTA is fast growing strategic economic reality, with only one setback, that is of India-Pakistan 'strategic straitjacket' fixed in a long standing political issue of Kashmir. Strategic leadership from both countries need to demonstrate sufficient courage, vision and will to transcend this 'strategic straitjacket', in order to facilitate and help unearth the economic and trade genius of one of the largest segments of human populations on the face of earth. Apart from SAFTA shaping into a powerful regional economic alliance; another 
economic strategic alliance can be visualized between the trio of China, India and Pakistan. These three coming together can make a strategic difference in the global business chunk. The realization of a free trade partnership between China, India and Pakistan can radically alter the traditional economic and trade realities of not only these close neighbors but also change the future course of the strategic global business and economic developments. The strategic economic alliance of these three countries can save its populations from the negative impact of globalization as currently experienced by them through MNCs and formulate a common strategic response to meet the economic and trade challenges of this century. This could be a trilateral strategic economic and trade parternership, making a historic difference in the lives of its peoples and transforming the whole region into unparallel economic prosperity. For the realization of this goal, leadership, political and economic have to grow out of the inherited 'strategic straitjackets' borne out of pseudo-historical and cultural misconceptions conditioned by a West European colonial experience. If the strategic leadership of these three neighboring states fails to respond creatively to the new global economic realities, this great region of tremendous economic potential may precipitate into economic failure, consequently being exploited by economic forces, which may not be under their control.

\section{Concluding Remarks}

Strategic leadership is more than a managerial practice; it's a kind of visionary dejavu emanating from a deep sense of working towards the collective betterment of business, society and people at large. Those who show a will to transcend the narrowness of 'strategic straitjackets'; have dreams and visions can, transform risk into advantage. The secret of sustainable growth lies 'within' firms, organizations and economies and not 'outside' the system. Only visionaries can feel and unlock that region of 'within' and make it into collective betterment of the humanity at large, what to speak of a business firm. The strategic leaders in contemporary corporate world must tamper their strategic vision of business seeking to acquire competitive advantage over their rivals, with a clear commitment towards moral and social responsibility, reinforced through a realization to protect the essential spiritual basis of managerial practice. If business loses touch with the spirit of vast majority of human beings, it can only lead to bitter conflicts, wars and intercultural rivalries. Rationality, moral responsibility and spirituality should go hand in hand in shaping the kind of strategic leadership, necessary to respond to the culturally and spiritually diverse workplace of the $21^{\text {st }}$ century. One unthoughtful strategic action in business, economics or politics can cause havoc

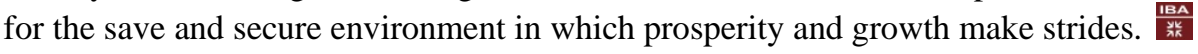

\section{References}

Baldrige, David, C.Floyd, Steven, W.Markoczy, Livin (2004). Are Managers From Mars and Academicians from Venus? Toward an Understanding of the relationship between Academic Quality and Practical Relevance. Strategic Management Journal.Vol 25, issue, 11 pp: 10631074.

Curcio, Richard, J.Wolf, Fran, M. (1996). Corporate Environmental Strategy: Impact upon Firm Value. Journal of Financial and Strategic Decisions.Vol:9, No: 2 Summer 1996.

Filbeck, G.Gorman, Raymond, F.Preece, Diana, C. 1996 Behavioral Aspects of the Intraindustry Capital Structure Decisions. Journal of Financial and Strategic Decisions. Vol:9,No:2,Summer,1996http//www.studyfinance.com/jfsd/.Retrieved on 11/02/04. 
Collins, J. (2001).Level 5 Leadership: The Triumph of Humility and Fierce Resolve, Harvard Business Review, 79(1):67-76.

Dreskey, Helen (2003). International Management; Managing Across Borders and Cultures. Prentice-Hall Inc.New Jersey.

Friedman. (1962). Capitalism and Freedom.Chicgo.Chicago University Press.

Finkelstein, S and Hambrick, D.C. (1996). Strategic Leadership: Top Executives and Their Effects on Organizations. St, Paul, MN, West Publishing Co.

Graedel, T.E.and AllenbyB.R. (1995). Industrial Ecology. New Jersey: Prentice-Hall.

Hammer, M and Stanton, S.A. (1997) .The Power of Reflection. Fortune, Nov.24, 291-296.

Hammel, G and Prahald, C.K. (1993). Strategy as Stretch and Leverage. Harvard Business Review, 71(2):75-84.

Hall, Pamela, L.Rieck, R. (1998). The Effect of Positive Corporate Social Actions of Shareholder Wealth. Journal of Financial and Strategic Decisions. Vol:11,No:2,1998. http//www.studyfinance.com/jfsd/.Retrieved on 11/02/04.

Hitt, Michael, H.Duane, Ireland, R. and Hoskisson, Robert, E. (2003). Strategic Management; Competitiveness and Globalization. Thomson South Western, Ohio.

Kets de Vries, M.F.R. (1995).Life and Death in Executive Fast Lane.San Francisco: Jossey Bass.

Larson, James, R.Sargis, Edward, G.Bareman, Christopher, W. (2004). Shared Knowledge and Subgroup influence during decision-making discussions. Journal of Behavioral Decision Making.Vol:17, 1ssue:4, pp: 245-262.

Liljenquist, Katie, A.Galinsky, Adam, D.Kary, LaraJ. (2004). Exploring the Rabbit Hole of Possibilities by Myself or with My Group: The Benefits and Liabilities of Activating Counterfactual Mindsets for Information Sharing and Group Coordination. Journal of Behavioral Decision-Making.Vol:17, Issue: 4, pp: 263-279.

Lassere, Phillppe (2003). Global Strategic Management.Palgrave Macmillan. New York.

Mintzberg, H. 1994 The Fall and Rise of Strategic Planning. Harvard Business Review, JanFeb: 107-114.

Maccoby, M. (2001).Successful Leaders Employ Strategic Intelligence, Research Technology Management, 44(3):58-60. (2001).Making Sense of Leadership Literature, Research Technology Management, 44(5):58-60.

Porter. (1979). How Competitive Forces Shape Strategy. Harvard Business Review, 57(2):37-145.

Peters, T.J. (2001), Leadership: Sad facts and Silver lining, Harvard Business Review, 79(11):121-128.

Schein, E.H.(1985). Organizational Culture and Leadership.San Francisco: Jossey Bass.

Teece, D.J. (2000). Managing Intellectual Capital: Organizational, Strategic and Policy Dimensions.Oxford: Oxford University Press.

Wright, P.Kroll, Mark, J and Parnell. (1996). Strategic Management; concepts and cases. New Jersey: Prentice-hall. 